\section{PILOTNÍ PROJEKTY SNOMED CT V ČESKÉ REPUBLICE}

Irena Rubešová, ÚZIS ČR; Libor Seidl, Institut pro podporu elektronizace zdravotnictví, z. s.; Miroslav Zvolský, ÚZIS ČR

\section{Anotace}

Česká republika je od roku 2012 členem neziskové organizace SNOMED International, jejímž hlavním úkolem je správa rízené klinické terminologie SNOMED CT. SNOMED CT má polyhierarchickou strukturu, jejímž základním stavebním kamenem je tzv. koncept. Koncepty jsou vzájemně „propojeny" definovanými vztahy. SNOMED CT je namapován na raadu mezinárodních klasifikací a standardů. SNOMED CT existuje v několika jazykových verzích, do češtiny zatím přeložen nebyl. SNOMED CT je implementován v elektronickém zdravotnictví mnoha států, bohužel jeho využití v ČR je zatím minoritní. ÚZIS ČR ve spolupráci s MZ ČR plánuje ve druhé polovině roku 2020 spustit několik pilotních projektů, které by otestovaly využitelnost SNOMED CT v našem zdravotnickém systému. Ve stádiu schvalování je projekt založení National release centre SNOMED CT ČR.

\section{Klíčová slova}

klinická terminologie, SNOMED CT, e-health, pilotní projekt

Systematized Nomenclature Of Medicine Clinical Terms (SNOMED (T) je řízená klinická terminologie používaná ve zdravotnictví více než 80 států světa. Tato terminologie je vyvíjena, spravována a distribuována neziskovou organizací Snomed International (SI), která sdružuje cca 35 členských států (např. USA, UK, Slovensko, Nizozemí, Norsko, Švédsko, Argentina). SI v roce 2018 zahájil spolupráci s Evropskou unií na projektu EU IMI/SNOMED/MedDRA. SNOMED CT je namapován na řadu mezinárodních klasifikací a standardů (např. MKN-10, LOINC). SNOMED CT existuje v několika jazykových variantách. Překlad do češtiny zatím nebyl realizován. Členské státy SI mají kromě celonárodní licence mnoho benefitů, mezi nejzajímavější patří možnost bezplatného absolovování e-learningového kurzu.

Základním kamenem SNOMED CT je takzvaný "koncept", který reprezentuje klinické konstatování a má své jedinečné identifikační číslo. V lednu 2020 vydal SI novou verzi mezinárodní edice SNOMED CT obsahující více než 350000 konceptů. Koncepty jsou navzájem uspořádány $\mathrm{v}$ polyhierarchických „Vztazích“. Vztah reprezentuje asociaci mezi dvěma koncepty. Př́klad hierarchického uspořádání konceptů je na Obr 1.
Česká republika je členem SI již od roku 2012. V současné době stojíme před otázkou, jak a zda SNOMED CT ve větší míře v ČR rozšiřit. Nyní je SNOMED CT využíván při standardizaci tzv. „patient summary“, které je vyvíjeno v rámci evropského projektu přeshraniční zdravotní péče (Zavedení přeshraničních služeb eHealth $v$ České republice projekt NIX.ZD podpořený z výzvy CEF TELECOM).

SNOMED CT je důležitým nástrojem pro zavedení služeb eHealth, protože umožňuje strojově čitelný popis klinické situace, kdy jednotlivé termíny používané $v$ klinické řeči mohou být identifikovány s definovaným konceptem, unikátně kódovány, a tedy zaznamenány ve shodě s klinickým významem. Zatímco běžně používané kódování například diagnóz nyní vycházi ze zaklasifikování (zařazení) daného prípadu do diagnostické skupiny často sdružující více konkrétních definovaných stavů, prípadně i stavy popsané obecněji, SNOMED CT se snaží popsat klinickou skutečnost na základě přesné shody s klinickým konceptem, je tedy mnohem detailnější. Státy, které již nabízejí svým občanům elektronické zdravotnictví, tzv. e-health (např. Nový Zéland, Island, Norsko) SNOMED CT pro jeho implementaci používají. Pokud se ČR chce vydat stejnou cestou, mělo by realizovat následující body:

- Rozšíření povědomí o SNOMED CT mezi zdravotnickou veřejností

- Definování, pro jaké účely se nám SNOMED CT hodí a kde ho chceme používat

- Zahájení překladu vybrané části SNOMED CT

Ve druhé polovině roku 2020 plánuje ÚZIS ČR ve spolupráci s MZ ČR spustit několik drobných pilotních projektů, které by potvrdily použitelnost a užitečnost zavedení SNOMED CT do klinické praxe v ČR (Tab 1). Mezi nejzásadnější patří založení National release centre SNOMED CT, které by mělo spravovat agendu SNOMED CT v České republice (Tab 2). Toto centrum musí být garantem české národní verze SNOMED CT (až bude přeložen do českého jazyka), např. by mělo kontrolovat správnost propojení nových verzí či spravovat český set proti aktualizované mezinárodní verzi.

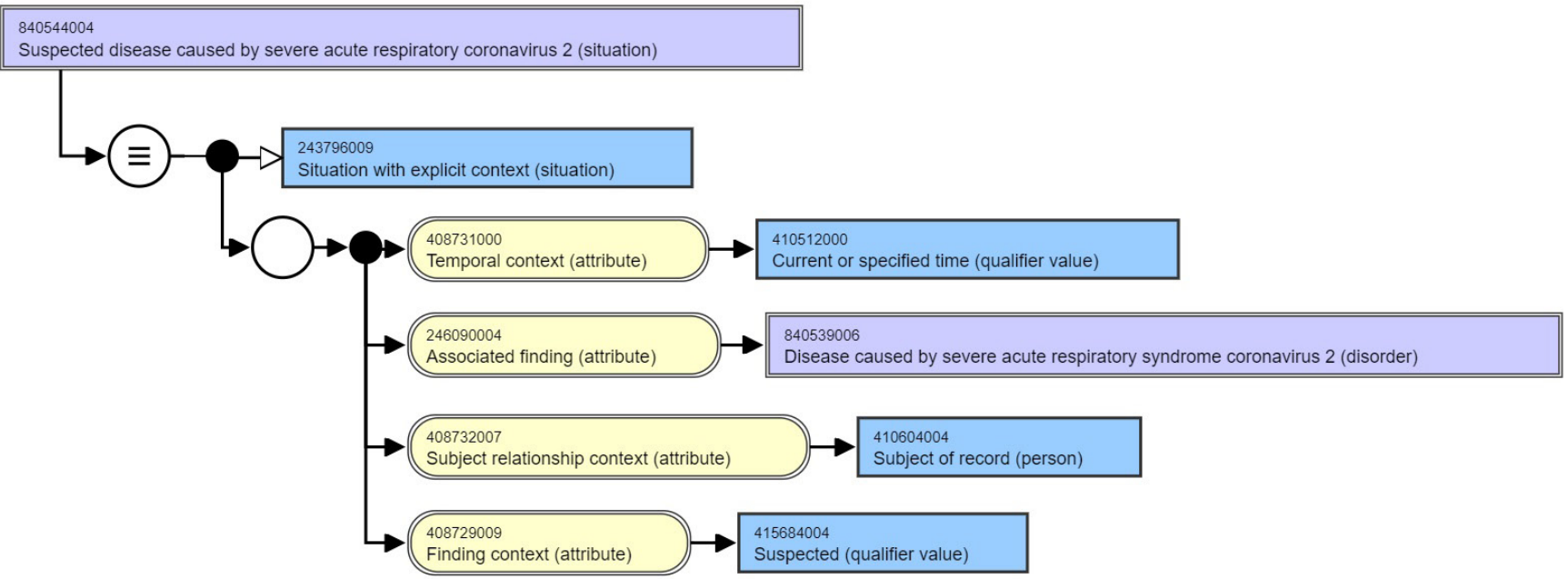


Tabulka 1 - Pilotní projekty SNOMED CT

\begin{tabular}{|c|c|c|}
\hline Číslo projektu & Název projektu & Popis projektu \\
\hline 1 & $\begin{array}{l}\text { Založení NRC } \\
\text { SNOMED CT }\end{array}$ & Založení „National release centre SNOMED CT”. Výstupem projektu bude funkční NRC SNOMED CT ČR. \\
\hline 2 & $\begin{array}{l}\text { Mikrobiologické } \\
\text { laboratoře }\end{array}$ & $\begin{array}{l}\text { Ověření vhodnosti použití a případné výhody SNOMED CT v oblasti mikrobiologických laboratoří, } \\
\text { konkrétně ke standardizaci předávání objednávek a výsledků mikrobiologických vyšetření (identifikace } \\
\text { agens, citlivost na ATB, ...). } \\
\text { Výstupem projektu bude národní terminologický standard využívající SNOMED CT. }\end{array}$ \\
\hline 3 & $\begin{array}{l}\text { Významné } \\
\text { procedury }\end{array}$ & $\begin{array}{l}\text { Lokalizace EU value setu „Major Surgical procedures“ (VS MSP). VS MSP bude v průběhu roku } 2020 \text { vytvořen } \\
\text { STF EU, následně bude zapotřebí ho přeložit do českého jazyka a provést mapování Seznamu zdravotních } \\
\text { výkonů (SZV) - pokud to bude možné - na tento VS. Součástí projektu bude také pilotní implementace } \\
\text { vykazování prímo pomocí Major surgical procedures, vytvoření SW podpory, a to včetně zpětného } \\
\text { mapování na Seznam zdravotních výkonů. }\end{array}$ \\
\hline 4 & $\begin{array}{c}\text { Mapování } \\
\text { položek } \\
\text { Národního } \\
\text { zdravotnického } \\
\text { informačního } \\
\text { systému na } \\
\text { termíny SNOMED } \\
\text { CT }\end{array}$ & $\begin{array}{l}\text { 1) Všechny položky datových modelů jednotlivých NZR } \\
\text { • popsat, zda se vztahuje k existujícímu obsahovému standardu - př. MKN-10, SZV, GCS, ISS, klasifikace } \\
\text { ČSÚ } \\
\text { • mapovat na SNOMED CT, pokud nelze mapovat, uvést tuto skutečnost } \\
\text { • dohledat, zda stejná nebo obsahově podobná položka je sbírána v jiném NZR } \\
\text { 2) Zveřejnit kompletní datovou strukturu NZR včetně mapování na položky SNOMED CT - interně pro } \\
\text { všechny metodiky a analytiky registrů } \\
\text { 3) Stanovit proces aktualizace a nutné kroky při změně datových modelů registrů a seznámit s nimi } \\
\text { metodiky a analytiky registrů }\end{array}$ \\
\hline 5 & Medikace & $\begin{array}{l}\text { Cesty podání léčiv nejsou dnes v rámci elektronické preskripce či záznamu medikace bud' kódovány vůbec } \\
\text { nebo se pro kódování používají různé, často lokálně vytvořené kódové systémy. Kódový systém EDQM je } \\
\text { sice využiván v rámci registračního procesu léčiv i přeshraniční výměny zdravotnické dokumentace v rámci } \\
\text { EU, z hlediska potřeb klinické praxe však není dostatečný, protože neumožnjuje přesnou specifikaci zpưsobu } \\
\text { podání léčiva. Výstupem projektu bude vytvoření národní referenční sady (výběr konceptů) SNOMED-CT, } \\
\text { použitelných pro kódový popis cesty podání léčiva a mapování této sady na kódový systém EDQM. }\end{array}$ \\
\hline
\end{tabular}

Tabulka 2 - Úkoly National release centre SNOMED CT ČR

\begin{tabular}{|c|l|}
\hline Úkol č. & \multicolumn{1}{c}{ Popis úkolu } \\
\hline $\mathbf{1}$ & Platba licenčních poplatků. \\
\hline $\mathbf{2}$ & Posuzování nasazení SNOMED CT, zabudování do existujících nebo vyvíjených projektů elektronického zdravotnictví \\
\hline $\mathbf{3}$ & Rozvržení a postupná realizace vývoje a udržování českého překladu \\
\hline $\mathbf{4}$ & Rozvíjení spolupráce s akademickou sférou a publikační aktivity ohledně pilotních projektů využívání SNOMED CT \\
\hline $\mathbf{5}$ & Rozvíjení komunikace směrem k producentům SW a možným uživatelům ze strany poskytovatelů zdravotních služeb \\
\hline
\end{tabular}

\section{Kontakt}

MUDr. Irena Rubešová

Ústav zdravotnických informací

a statistiky ČR

Palackého náměstí 357/4

12801 Praha 2

email:Irena.Rubesova@uzis.cz 